\title{
Significance of early diagnosis and early intervention in early childhood hearing loss
}

\author{
Erken çocukluk dönemi işitme kaybında erken tanı ve erken \\ müdahalenin önemi \\ Ayşe Sanem Şahli ${ }^{1}$
}

\section{Article History}

Received : 04 June 2018

Revised : 04 July 2018

Accepted : 08 July 2018

Online : 10 July 2018

Article Type

Review Article

\author{
Makale Geçmişi \\ Geliş : 04 Haziran 2018 \\ Düzeltme : 04 Temmuz 2018 \\ Kabul : 08 Temmuz 2018 \\ Çevrimiçi : 10 Temmuz 2018 \\ Makale Türü \\ Derleme Makale
}

\begin{abstract}
Hearing loss is an important problem interfering with the propagation of acoustic signal starting from the external ear to the primary auditory center of the brain. The congenital hearing loss is an important and common disorder that can lead to many consecutive negative conditions when it is not diagnosed and treated within the first few months of life. Early Hearing Diagnosis and Intervention programs becoming more increasingly popular in recent years aim to avoid the negative effects of hearing loss. The main goal of these programs is to maximize the linguistic proficiency and literacy development of children with hearing loss. Children who are not given the appropriate opportunities for learning language fall behind their peers with normal hearing in communication, reading, cognitive and socio-emotional development. Delays occurring in these fields manifest as a lower educational status and vocational employment problem in adulthood. Therefore, diagnosing and treating hearing loss as early as possible is extremely important.
\end{abstract}

Keywords: Child; hearing; hearing loss; early diagnosis; early intervention

Öz: İşitme kaybı, akustik sinyalin dış kulaktan başlayıp, beyindeki primer işitme merkezine kadar olan yol boyunca ilerlemesine engel olan önemli bir problemdir. Konjenital işitme kayıpları, yaşamın ilk birkaç ayı içerisinde tanılanıp tedavi edilmediğinde, birbirini izleyen birçok olumsuz duruma neden olabilen önemli ve yaygın görülen bir bozukluktur. Son yıllarda giderek yaygınlaşan Erken İşitme Tanı ve Müdahale programları ile işitme kaybının olumsuz etkilerinin önüne geçilmesi amaçlanmaktadır. Bu programların temel amacı, işitme kayıplı çocukların dilsel yeterliliklerini ve okuma-yazma gelişimlerini en üst düzeye çıkarmaktır. Dili öğrenmek için uygun firsatlar verilmeyen çocuklar, iletişim, okuma, bilişsel ve sosyo-emosyonel gelişimde işiten yaşıtlarının gerisinde kalmaktadır. Bu alanlarda meydana gelen gecikmeler, yetişkinlikte karşımıza daha düşük bir eğitim düzeyi ve mesleki istihdam problemi olarak çıkmaktadır. Bu nedenle işitme kaybının mümkün olan en erken dönemde tanılanması ve tedavi edilmesi son derece önemlidir.

Anahtar Kelimeler: Çocuk; işitme; işitme kaybı; erken tanı; erken müdahale 


\section{INTRODUCTION}

Hearing loss is the inability to perceive environmental sounds and speech sounds as a result of pathologies occurring in the external, middle, inner ear, and auditory pathways due to various causes. The impact of sensorial experience on neural structures and functions vary by age. The effect of peripheral sensorial activity loss is much more prominent and important when it occurs during the critical developmental period. Thus, the success of interventions (ie. cochlear implant) performed for hearing loss within this period is associated with a better development of neural functions (Madell and Flexer, 2014). The factors during the prenatal, natal and postnatal periods of infants and children cause the emergence of hearing loss with different traits. The risk factors listed below are the main causes for the formation of hearing loss in children. If the child is affected by even two of these factors, the risk of hearing loss is over 90\% (Joint Committee on Infant Hearing, 2000).

These factors include;

1. The family history of hearing loss occurring in childhood

2. Premature birth, low birth weight

(1500 grams or less)

3. The syndromes accompanied by characteristic hearing loss

4. Bacterial meningitis, encephalitis, infections such as mumps

5. Cytomegalovirus, herpes, rubella, syphilis, toxoplasmosis infections

6. Hyperbilirubinemia, persistent pulmonary hypertension secondary to mechanical ventilation

7. Neurofibromatosis, osteopetrosis, Usher's syndrome

8. Head traumas

9. Neurodegenerative diseases

10. Recurrent persistent otitis (lasting more than three months) (Joint Committee on Infant Hearing, 2000; Belgin, 1992).

Hearing loss is classified diversely according to the localization of pathology (the type of hearing loss), according to the time it develops chronologically, whether it is unilateral or bilateral and according to the degree of hearing loss. It is classified as transmission, sensorineural, mixed, functional (nonorganic) and central hearing loss according to the localization of pathology while it is classified as prelingual, perilingual and postlingual according to the time it develops. The effects of hearing loss occur most when it is bilateral, severe and very severe and prelingual (Sahli, 2014). 


\section{Significance and Effects of the Degree of Hearing Loss}

The degree of hearing loss is a determinative factor for the ability to understand speech, communication skills and development fields in individuals with hearing loss without a visual clue. Even in case of mild hearing loss, the speech and language skills of the child are influenced. As the degree and duration of loss increases, social and emotional problems, communication difficulties and behavior problems such as introversion, restlessness and aggression are observed (Madell and Flexer, 2014; Sahli, 2014).

The involvement level of the child from the hearing loss is closely related to the degree of hearing loss. As the degree of hearing loss increases, its effects on children increases as well. Mild-to-moderate hearing loss, which occurs before and during the child's gaining language process, manifests itself with articulation disorders as well as delayed language and speech development. In case of moderate and severe hearing loss, in addition to these, impairments in sound quality and speech rhythm accompany while learning difficulties, cognitive problems, distractibility and behavior problems are added on. The severity of hearing loss in children is shown in Table 1. Accordingly, children with the hearing of -10-15 dB are accepted as 'normal hearing '. Hearing loss over $15 \mathrm{~dB}$ affects speech and language development negatively in infants and children (Clark, 1981; ASHA, 2018).

Table 1. Degree of hearing loss in children

\begin{tabular}{ll}
\hline Hearing loss range (dB HL) loss & Degree of hearing \\
\hline$-10-15 \mathrm{~dB}$ & Normal \\
\hline $16-25 \mathrm{~dB}$ & Slight \\
\hline $26-40 \mathrm{~dB}$ & Mild \\
\hline $41-55 \mathrm{~dB}$ & Moderate \\
\hline $56-70 \mathrm{~dB}$ & Moderately severe \\
\hline $71-90 \mathrm{~dB}$ & Severe \\
\hline $91+$ & Profound \\
\hline
\end{tabular}

The sense of hearing is quite important for speech, language development, communication and learning. The basic problem in hearing loss is the interference of sound signals with the transmission to the brain. With the technology advancements in amplification devices (hearing aids, cochlear implants, etc.), auditory neural connections can be transmitted to the brain, the brain can be stimulated and thereby, the language, speaking, reading, and academic skills of children with hearing loss can improve. The listening experiences of infants and younger children during the first 3.6 years of life in which neuroplasticity is the fastest are very important. Listening experiences are one of the most important factors for the speech and 
language development of children (Buran et al, 2014). The lack or insufficiency of auditory experience causes 'linguistic deprivation'. Infants and children who have difficulty in listening due to hearing loss are at risk for developmental delays. Childhood hearing losses have a significant negative effect on language, social and emotional development and academic success. These risks can be minimized by early diagnosis and appropriate intervention programs for hearing loss affecting hearing skills and language development (Lederberg, 2006; Mukuria and Eleweke, 2010).

According to the National Institute on Deafness and Other Communication Disorders, approximately 12,000 new infants with hearing loss are diagnosed each year in the world. Also, the number of infants and children aged between 0 and 3 years who undergo newborn hearing screening tests and who have a late-onset hearing loss is approximately between 4,000 and 6,000. Each year, approximately 16,000-18,000 new infants and toddlers are diagnosed with hearing loss (Madell and Flexer, 2014).

The effects of early-onset hearing loss on children are usually prominent in the following areas. These include;

1. Delay in the development of receptive and expressive communication skills (speech and language),

2. Learning difficulties secondary to language delays and low academic success,

3. Social isolation and decreased self-esteem caused by communication disorders,

4. Occupational choices (ASHA,2014).

The studies conducted indicates that any degree of hearing loss, if not diagnosed or treated adequately and appropriately, causes adverse effects on the speech, language, academic, emotional and psychosocial development of children (Belgin et al, 2013; Tomblin, 2005). The secondary effects of hearing loss rather than itself affects the child's development in a negative way negatively. Infants born with hearing loss and diagnosed early and treated appropriately have better language, speech, cognitive and social skills compared to late diagnosed and late treated children (Calderon and Naidu, 1999; Nittrouer and Burton, 2001; Sahli, 2014).

\section{Hearing loss and Neuroplasticity}

The biggest problem occurring in children with hearing loss is the transmission of sounds to the brain (auditory cortex). The aim of hearing aids and cochlear implants is to provide the auditory 
neural connections' transmission, stimulation, growth of the brain during the process of acquiring speech, language, reading, and academic skills.

'Hearing' is the most important factor in acquiring speaking, reading, and cognitive skills With today's amplification technologies (cochlear implant etc.), early diagnosis and early intervention approaches, the auditory brain stimulation of infants is possible. The studies on brain development denote that the sensorial stimulation of auditory centers/cortexes is quite important and that the auditory pathways in the brain influence the actual organization. The brain remodels and organizes itself according to the stimulations received from its surrounding. On the other hand, if sounds do not reach to the auditory cortex of the brain partially or completely due to hearing loss, the brain organizes itself in a different way (Madell and Flexer, 2014; Kraus and Anderson, 2012; Sahli, 2014).

If we want to remember or learn some things that we hear, we should hear them loudly and clearly, because memory can only code the original signal as far as it is clear. As in amplification technologies, improving the signal is of great importance in terms developing auditory-neural pathways and enabling brain stimulation. Neural imaging techniques show that the areas in the primary and secondary auditory cortex are more active when the child is listening and reading. In other words, the significant awareness of speech sound language, which means phonologic or is a phonemic awareness is the basis for the development of literacy skills. Significant neural deficits occur in the high-level hearing centers of the brain due to the lack of long-term auditory stimulation and auditory stimulation directly affects speech perception and language processing in human. For the maturation of auditory pathways, acoustic stimulation should be early and continuous. Because the maturation of central auditory pathways is the primary determinant of children' s language and speech skill development. The research indicates that children who receive cochlear implants in a very early period (around 1 year), although they are within the critical developmental period, they benefit more in terms of the plasticity of auditory pathways compared to those with later implantation. In short, although the first 3-3.6 years of life are extremely important for neuroplasticity, it is much more important in younger infants (Sharma et al, 2009; Cardon and Sharma, 2011). Because a training program supporting the development of amplification and auditory skills is quite necessary for a very rapidly growing brain in infants. In case of infants with hearing loss, in the absence of sounds, the brain reorganizes itself by receiving stimuli from other senses (primary visual sensation) and its auditory neural capacity decreases. This process is called 'cross-modal reorganization'. With the amplification in the first year of life and subsequently performed 
implantation, the brain, which is stimulated by more auditory inputs, is organized normally and its auditory capacity increases. Early amplification and implantation synchronize the activity in the cortical regions (Madell and Flexer, 2014; Kraus and Anderson,2012; Sahli, 2014). Another study investigating the P1 latencies of 231 children with congenital hearing loss who received cochlear implants reported that those in whom implantation was performed in the early period (under 3.6 years) reached normal P1 latency within 6-8 months after implantation. It was stated that individuals who received cochlear implant after 6.5-7 years of age, even after long years after implantation, had delayed/abnormal latencies whereas some of those who started to use implants between the ages of 3.6-7 years had normal P1 latency and some did not have. The children received an implant at an early age attained a normal P1 latency short after the procedure while the P1-N1-P2 complex developed after a long implant experience (Kral and Sharma, 2012). In the study by Gilley at al. in which they examined the P1 cortical area activations of early and late implant users with electromagnetic brain tomography, they reported that those with early implants had activation areas similar to normally hearing people whereas, although a parietotemporal cortex activation was observed in those who received implant after 7 years of age, no activation was encountered in the auditory cortical areas (Gilley et al, 2008). With the development of newborn screening, early diagnosis and intervention programs, the number of infants and young children who received a cochlear implant is ever increasing. Early cochlear implantation allows infants with hearing loss to spend the critical period (0-2 years) which is crucial for speech and language development effectively. Recent studies showed that children received an implant between 4-36 months of age experienced a different process of hearing and language skills in terms of both quality and quantity compared to children over 36 months of age. Whereas children received an implant younger than 2 years of age had the chance to catch up their peers with normal hearing. For this reason, it is very important to be exposed to speech sound as early as possible for speech and language development (Miyamoto et al, 2008; Roland et al, 2009; Colletti, 2009; . Artieres et al,2009). Ninety children with implant were examined in a study aiming to compare the effects of cochlear implantation performed under and over 2 years of age on auditory perception.

Children were divided into three groups according to the age at implantation. The first group included the patients in whom implantation was performed under two years of age (mean age: 20.4 months), the second group included those received an implant between the ages of 2 and 4 years whereas the third group included those received an implant between the ages of 4 and 6 years. Audiometric perception tests were administered to all of the children in the whole group 
before and 2 days, 1, 3, 6, 12 months, 2 and 3 years after implantation and results were compared. As a result of the study, although the children in all age groups showed improvement, the children received an implant under 2 years of age had a significantly faster and statistically significant improvement in auditory perception compared to the other groups (Anderson, 2004). In a study conducted to assess the effect of age on cochlear implantation, children received a cochlear implant under 3 years of age were compared with their normally hearing peers. According to age at implantation, children were divided into three groups, namely, 12-18 months (n: 45), 19-23 months (n: 32) and 24-36 months (n: 30)(107 children in total). The researchers who administered the Infant-Toddler Meaningful Auditory Integration Scale (ItMAIS), an auditory perception scale, to the families of the children via interview before and 3, 6, and 12 months after implantation indicated that the scores of the children with hearing loss were near to zero and all three groups showed improvement after implantation. The study concluded that the children in two groups which received implants under 2 years of age (12-18 months and 19-23 months) performed better than those who received implants between 24-36 months of age and there was no statistically significant difference between these two younger age groups (Robbins et al, 2004).

In another study assessing the auditory improvements of the infants and children receiving cochlear implants under 2 years of age, 63 children using cochlear implant were evaluated and compared with their normally hearing peers. It was observed that the children with the mean age of 14.8 months at implantation and with the mean hearing age of 10.1 months got a maximum score at 22 months as hearing age and at 38 months as chronological age. Whereas the maximum score was attained at 24 months in normally hearing children. However, it was emphasized that children underwent implantation under 12 months of age had a higher score than those received an implant over 12 months of age (May-Mederake, 2010).

The benefits of cochlear implantation within the first 3.6 years of life in children with congenital hearing loss were also shown in studies. Because the central auditory system has the maximum plasticity potential within this age range. P1 latency, a component of auditory evoked potentials, decreases rapidly in children who received a cochlear implant under 3.6 years of age and reaches its normal value (Kral and Sharma,2012). On the contrary to this information, in children who start to use cochlear implants after 7 years of age have abnormal cortical responses even if they use them for many years (Ponton et al,1996). 


\section{Early Diagnosis and Early Intervention Programs}

Newborn hearing screening Programs form the basis of early diagnosis and treatment services. The Early Diagnosis and Intervention Programs emphasize that all newborns should be screened for hearing before they finish their first month that infants who cannot pass the screening test should undergo a detailed audiologic evaluation before finishing their third months, whereas the infants whose hearing loss are confirmed should benefit from appropriate intervention services to be provided by the medical institutions and educators that are specialized in infant and children hearing loss before they finish their sixth months. Regardless of the hearing screening results, it is very important to keep the communicational improvements starting in the second month of all infants with or without risk factor under observation (AAP, 2002; Joint Committee on Infant Hearing, 2007-2013).

A successful early diagnosis and intervention program should include the following features;

- Hearing screening before one month of age (hearing screening)

- Diagnosis of hearing loss before three months of age(diagnosis of hearing loss)

- Initiation of appropriate intervention services (amplification-auditory habilitation) for the infant with hearing loss before six months of age (appropriate intervention services)

- Coordination of the services provided for the child (coordination of services)

- Providing a competent family support culturally (family support) (Joint Committee on Infant Hearing, 2007).

Diagnosing newborns in the early period in terms of hearing loss and initiation of their treatments can prevent the negative effects of hearing loss as well as those of developmental and communicational field. In a retrospective study of ours examining the characteristics of newborns with hearing loss related to hearing loss, amplification and intervention, the mean age of using hearing aid was 5.83 months and onset age of auditory-verbal training was found to be 6.7 months. The majority of newborns with a confirmed hearing loss $(73.3 \%)$ had a severe or very severe hearing loss. Of them, $43.3 \%$ were using hearing aids and the remaining $56.7 \%$ were using cochlear implants. For the cochlear implant group, the mean age at implantation was observed to be 13.17 months (Sahli et al, 2012). It is striking that these data are consistent with the early diagnosis and intervention programs accepted worldwide. A lot of information and innovation about the assessment of hearing, audiological tests, treatment and re/habiliation of hearing loss in infants and young children are available today. The impact of newborn hearing screening is great with respect to this condition. In recent years, as a result of 
improvements in screening equipment and test procedures worldwide, the newborn hearing screening programs have increased rapidly and the rate of newborns screened for hearing loss before being discharged from the hospital has increased up to $90 \%$.

'A family' cooperating as a member of a team with professionals forms the basis of the success of early diagnosis and intervention programs (Calderon, 2000;Jackson,2009).Within the program, the duties and responsibilities of every member of the team must be well defined and clearly understood. The basic members of the team include maternity hospital, family, pediatricians, primary healthcare professionals dealing with the infant one-to-one, otorhinolaryngologist, audiologist, educational audiologist, speech-language therapist, teacher of hearing impaired and other health professionals serving within the scope of early diagnosis and intervention program(Joint Committee on Infant Hearing, 2007; ASHA, 1994). Also, neurology, genetics, ophthalmology, supporting family education and counseling units are members of this team. Since more than $50 \%$ of congenital hearing loss occurs secondary to genetic causes, genetic experts should play an increasingly important role in neonatal screening, diagnosis and intervention services (Calderon et al,1998).

\section{CONCLUSION}

Hearing losses occurring in early childhood affects many fields of development negatively. Especially, the onset age, type, and degree of hearing loss, age at diagnosis, usage of a hearing aid or cochlear implant, and level of support given by family are the leading factors in the development of the child. Nowadays, with early diagnosis and early intervention programs, the vast majority of children with hearing loss are protected from the negative effects of hearing loss and can complete their development similar to their normally hearing peers.

Newborn hearing screening programs have been implemented effectively in our country since 2004. The scereening program is the first step in early diagnosis. Early diagnosis of hearing loss provides convenience for health professionals (especially audiologists) in early amplification (hearing aid and/or cochlear implant). Although our country is in good condition on early detection of hearing loss and early amplification, further research is needed on early intervention for hearing loss. Auditory-Verbal Therapy (AVT) is the most effective communication and habilitative method for infants with hearing loss. However frequency of implementation of AVT is still insufficient in our country. One of the most important steps in early intervention is the education of children with hearing loss. For this reason, there is a need 
for awareness education for professionals/parents about AVT and advanced scientific researches for children with hearing loss.

\section{REFERENCES}

AAP (American Academy of Pediatrics). (2002). Medical Home Initiatives for Children with Special Needs Project Advisory Committee. The medical home. Pediatrics, (110), 184186.

Anderson, I., Weichbold, V., \& Dhaese, P. (2004). Three-year follow-up of children with openset speech recognition who use the MED-EL cochlear implant system. Cochlear Implants International, 5(2), 45-57.

Artières, F., Vieu, A., Mondain, M., Uziel, A., \& Venail, F. (2009). Impact of early cochlear implantation on the linguistic development of the deaf child. Otology \& Neurotology, 30(6), 736-742.

ASHA (American Speech-Language Hearing Association). (2014). How does your child hear and talk?. Retrived from: www. asha.org, Accessed: August 2014.

ASHA (American Speech-Language-Hearing Association). (1994). Service provision under the Individuals with Disabilities Education Act (IDEA-Part $\mathrm{H}$ ) to children who are deaf and hard of hearing ages birth to 36 months. ASHA, 36, 117-121.

ASHA (American Speech-Language-Hearing Association). (2018). Degree of Hearing Loss. Retrived from: https://www.asha.org/public/hearing/degree-of-hearing-loss/, Accessed: January 2018.

Belgin, E. (1992). The causes of hearing loss in our country-special education approaches. Special Education Journal, (1), 6-7.

Belgin, E. Sahli, A.S., Ozdek, A., Akın, I., Yaylamaz, E., Tuncer, U., Tezer, N., Sahin, R. (2013). Auditory perception and speech intelligibility results of late cochlear implanted children in Turkey: A multicentric research. 29th Politzer Society Meeting, Antalya.

Buran, B. N., Sarro, E. C., Manno, F. A., Kang, R., Caras, M. L., \& Sanes, D. H. (2014). A sensitive period for the impact of hearing loss on auditory perception. Journal of Neuroscience, 34(6), 2276-2284.

Calderon, R. (2000). Parental involvement in deaf children's education programs as a predictor of child's language, early reading, and social-emotional development. Journal of Deaf Studies and Deaf Education, 5(2), 140-155.

Calderon, R., \& Naidu, S. (1999). Further support for the benefits of early identification and intervention for children with hearing loss. Volta review, 100(5), 53-84.

Calderon, R., Bargones, J., \& Sidman, S. (1998). Characteristics of hearing families and their young deaf and hard of hearing children. American Annals of the Deaf, 143(4), 347. 
Cardon, G., \& Sharma, A. (2011). Cortical auditory evoked potentials in auditory neuropathy spectrum disorder: clinical implications. Perspectives on Hearing and Hearing Disorders in Childhood, 21(1), 31-37.

Clark, J. G. (1981). Uses and abuses of hearing loss classification. ASHA, 23(7), 493-500.

Colletti, L. (2009). Long-term follow-up of infants (4-11 months) fitted with cochlear implants. Acta Oto-Laryngologica, 129(4), 361-366.

Gilley, P. M., Sharma, A., \& Dorman, M. F. (2008). Cortical reorganization in children with cochlear implants. Brain Research, 1239, 56-65.

Jackson, C. W. (2009). Family involvement in early intervention for children who are deaf or hard of hearing. Early Childhood Services, 3(1), 77-97.

Joint Committee on Infant Hearing (2000). American Academy of Audiology, American Academy of Pediatrics, American Speech-Language-Hearing Association, Directors of Speech and Hearing Programs in State Health and Welfare Agencies, et al. Position statement: principles and guidelines for early hearing detection and intervention programs. Pediatrics, 106(4), 798-817.

Joint Committee on Infant Hearing. (2007). Detection and intervention programs year 2007 position statement: principles and guidelines for early hearing. Pediatrics, 120, 898921.

Joint Committee on Infant Hearing. (2013). Supplement to the JCIH 2007 position statement: Principles and guidelines for early intervention after confirmation that a child is deaf or hard of hearing. Pediatrics, 131(4), e1324-e1349.

Kral, A., \& Sharma, A. (2012). Developmental neuroplasticity after cochlear implantation. Trends in neurosciences, 35(2), 111-122.

Kraus, N., \& Anderson, S. (2012). Hearing matters: Hearing with our brains. The Hearing Journal, 65(9), 48.

Lederberg, A. (2006). Language development of deaf children with hearing parents. Encyclopedia of Language \& Linguistics (Second Edition), 361-368.

Madell, J.R., Flexer, C. (2014). Why Hearing is Important in Children, Pediatric Audiology: Diagnosis, Technology and Management. Newyork: Thieme Medical Publishers

May-Mederake, B., Kuehn, H., Vogel, A., Keilmann, A., Bohnert, A., Mueller, S., ... \& Streitberger, C. (2010). Evaluation of auditory development in infants and toddlers who received cochlear implants under the age of 24 months with the LittlEARS ${ }^{\circledR}$ Auditory Questionnaire. International journal of pediatric otorhinolaryngology, 74(10), 11491155 .

Miyamoto, R. T., Hay-McCutcheon, M. J., Iler Kirk, K., Houston, D. M., \& Bergeson-Dana, T. (2008). Language skills of profoundly deaf children who received cochlear implants under 12 months of age: a preliminary study. Acta oto-laryngologica, 128(4), 373-377. 
Mukuria, G.M., Eleweke, C.J. (2010). Educating Children with Deafness and Hearing Impairments. International Encyclopedia of Education (Third Edition), 628-633.

Nittrouer, S., \& Burton, L. T. (2001). The Role of Early Language Experience in the Development of Speech Perception and Language Processing Abilities in Children with Hearing Loss. Volta Review, 103(1), 5-37.

Ponton, C. W., Don, M., Eggermont, J. J., Waring, M. D., Kwong, B., \& Masuda, A. (1996). Auditory system plasticity in children after long periods of complete deafness. Neuroreport, 8(1), 61-65.

Robbins, A. M., Green, J. E., \& Waltzman, S. B. (2004). Bilingual oral language proficiency in children with cochlear implants. Archives of Otolaryngology-Head \& Neck Surgery, 130(5), 644-647.

Roland, J.T., Cosetti, M., Wang, K.H., Immerman, S., Waltzman, SB.(2009). Cochlear implantation in the very young child: long-term safety and efficacy. Laryngoscope, 119 (11), 2205-2210.

Sahli, A.S. (2014). Educational Approaches to Hearing Loss (Chapter 22). Ear Nose Throat Diseases and Head Neck Surgery, Book Ed. Dr. Muharrem Gerceker, Academician Medicine Bookstore.

Sahli, A.S., Sevinc, S., Belgin, E. (2012). General Profiles of Hearing Impaired Newborns in Turkey: Characteristics of Hearing Loss, Amplification and Intervention. NHS 2012 Conference, Cernobbio (Como Lake), Italy.

Sharma, A., Nash, A. A., \& Dorman, M. (2009). Cortical development, plasticity and reorganization in children with cochlear implants. Journal of communication disorders, 42(4), 272-279.

Tomblin, J. B., Barker, B. A., Spencer, L. J., Zhang, X., \& Gantz, B. J. (2005). The effect of age at cochlear implant initial stimulation on expressive language growth in infants and toddlers. Journal of Speech, Language, and Hearing Research, 48(4), 853-867. 